\title{
Development of Mini-Compact Tension Test Method for Determining Fracture Toughness Master Curves for Reactor Pressure Vessel Steels
}

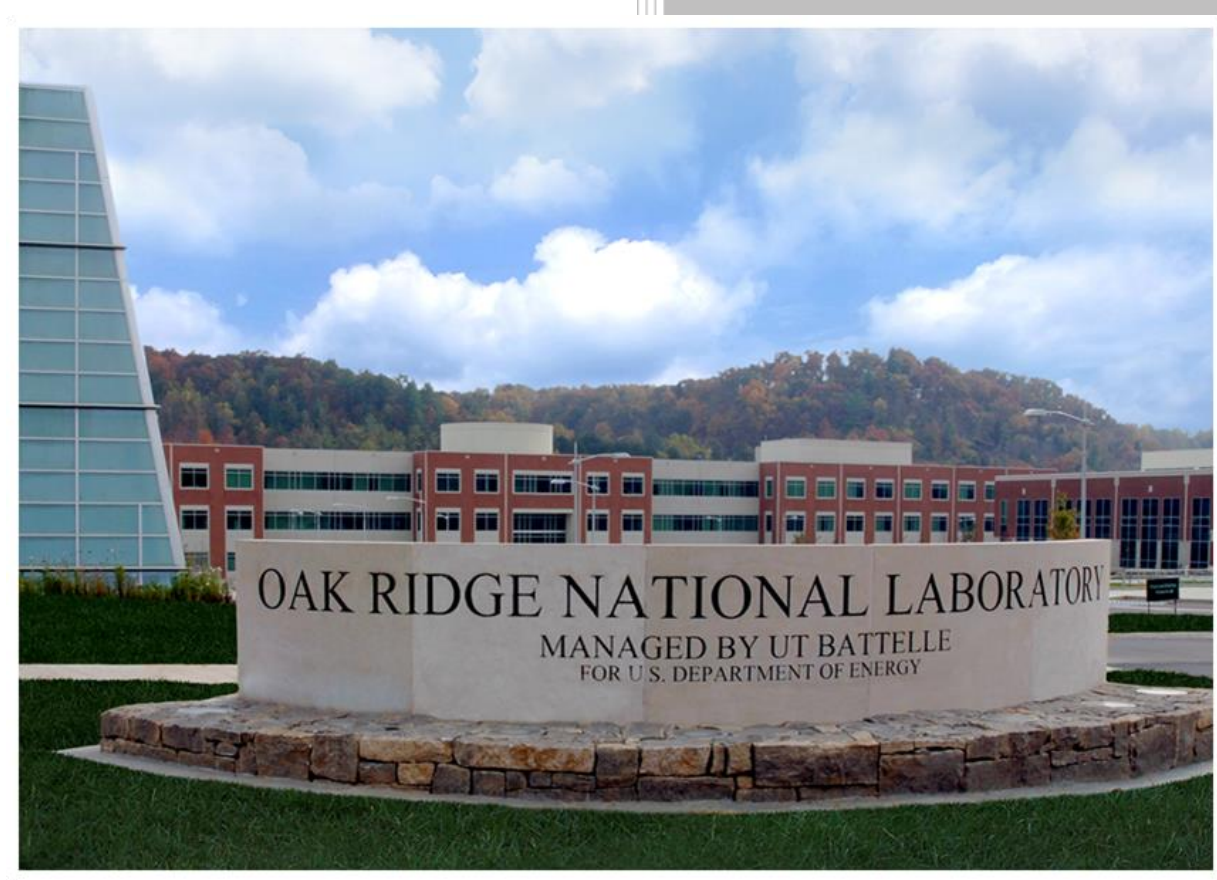

Approved for public release. Distribution is unlimited.

OAK RIDGE NATIONAL LABORATORY MANAGED BY UT-BATTELLE FOR THE US DEPARTMENT OF ENERGY
Mikhail A. Sokolov

May 2017 


\section{DOCUMENT AVAILABILITY}

Reports produced after January 1, 1996, are generally available free via US Department of Energy (DOE) SciTech Connect.

Website http://www.osti.gov/scitech/

Reports produced before January 1, 1996, may be purchased by members of the public from the following source:

National Technical Information Service

5285 Port Royal Road

Springfield, VA 22161

Telephone 703-605-6000 (1-800-553-6847)

TDD 703-487-4639

Fax 703-605-6900

E-mail info@ntis.gov

Website http://www.ntis.gov/help/ordermethods.aspx

Reports are available to DOE employees, DOE contractors, Energy Technology Data Exchange representatives, and International Nuclear Information System representatives from the following source:

Office of Scientific and Technical Information

PO Box 62

Oak Ridge, TN 37831

Telephone 865-576-8401

Fax 865-576-5728

E-mail reports@osti.gov

Website http://www.osti.gov/contact.html

This report was prepared as an account of work sponsored by an agency of the United States Government. Neither the United States Government nor any agency thereof, nor any of their employees, makes any warranty, express or implied, or assumes any legal liability or responsibility for the accuracy, completeness, or usefulness of any information, apparatus, product, or process disclosed, or represents that its use would not infringe privately owned rights. Reference herein to any specific commercial product, process, or service by trade name, trademark, manufacturer, or otherwise, does not necessarily constitute or imply its endorsement, recommendation, or favoring by the United States Government or any agency thereof. The views and opinions of authors expressed herein do not necessarily state or reflect those of the United States Government or any agency thereof. 
ORNL/TM- 2017/275

Light Water Reactor Sustainability Program

\title{
Development of Mini-Compact Tension Test Method for Determining Fracture Toughness Master Curves for Reactor Pressure Vessel Steels
}

\author{
M.A. Sokolov \\ Materials Science and Technology Division \\ Oak Ridge National Laboratory
}

Date Published: May 2017

Prepared under the direction of the

U.S. Department of Energy

Office of Nuclear Energy

Light Water Reactor Sustainability

Materials Aging and Degradation Pathway

Prepared by

OAK RIDGE NATIONAL LABORATORY

Oak Ridge, Tennessee 37831-6283

Managed by

UT-BATTELLE, LLC

for the

U.S. DEPARTMENT OF ENERGY

under contract DE-AC05-00OR22725 
This page intentionally left blank 


\section{CONTENTS}

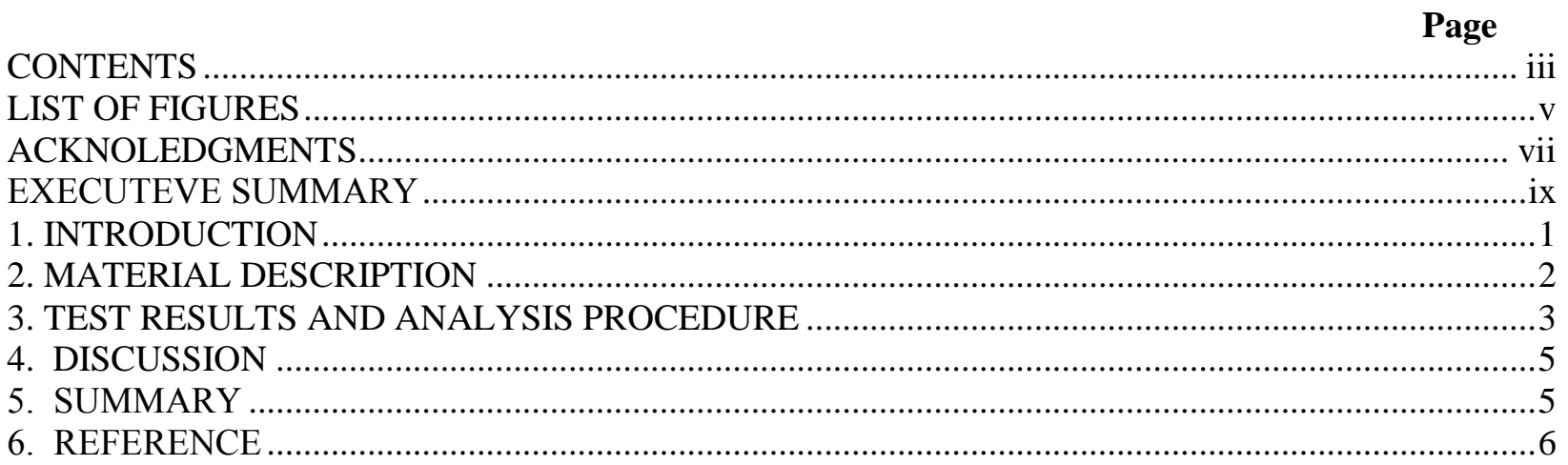


This page intentionally left blank 


\section{LIST OF FIGURES}

Figure

Page

Figure 1. Unirradiated Midland beltline weld $\mathrm{K}_{\mathrm{Jc}}$ data normalized to $1 \mathrm{~T}$ equivalence; the mater curve and $2 \%$ tolerance bound and $\mathrm{K}_{\mathrm{J}-\mathrm{R}}$ curve limit curve [5]. .2

Figure 2. Layout of Mini-CT within broken Charpy half and overall dimensions of Mini-CT specimen..

Figure 3. Fracture toughness of Midland beltline weld determined by Mini-CT specimens. .5 
This page intentionally left blank 


\section{ACKNOWLEDGMENTS}

This research was sponsored by the U.S. Department of Energy, Office of Nuclear Energy, for the Light Water Reactor Sustainability Research and Development effort. The author extends his appreciation to Dr. Keith Leonard for programmatic support and Dr. Xiang Chen for technical review. 
This page intentionally left blank 


\section{EXECUTIVE SUMMARY}

Small specimens are playing the key role in evaluating properties of irradiated materials. The use of small specimens provides several advantages. Typically, only a small volume of material can be irradiated in a reactor at desirable conditions in terms of temperature, neutron flux, and neutron dose. A small volume of irradiated material may also allow for easier handling of specimens. Smaller specimens reduce the amount of radioactive material, minimizing personnel exposures and waste disposal. However, use of small specimens imposes a variety of challenges as well. These challenges are associated with proper accounting for size effects and transferability of small specimen data to the real structures of interest.

Any fracture toughness specimen that can be made out of the broken halves of standard Charpy specimens may have exceptional utility for evaluation of reactor pressure vessels (RPVs) since it would allow one to determine and monitor directly actual fracture toughness instead of requiring indirect predictions using correlations established with impact data. The Charpy V-notch specimen is the most commonly used specimen geometry in surveillance programs.

Validation of the mini compact tension specimen (mini-CT) geometry has been performed on previously well characterized Midland beltline Linde 80 (WF-70) weld in the unirradiated condition. It was shown that the fracture toughness transition temperature, $\mathrm{T}_{\mathrm{o}}$, measured by these Mini-CT specimens is almost the same as $T_{0}$ value that was derived from various larger fracture toughness specimens. Moreover, an International collaborative program has been established to extend the assessment and validation efforts to irradiated Linde 80 weld metal. The program is underway and involves the Oak Ridge National Laboratory (ORNL), Central Research Institute for Electrical Power Industry (CRIEPI), and Electric Power Research Institute (EPRI). The irradiated Mini-CT specimens from broken halves of previously tested Charpy specimens of Midland beltline weld have been machined and just arrived to ORNL as part of this international collaboration. The ORNL will initiate tests of the irradiated Linde 80 weld in FY2017 and results of this international program will be reported in FY2018. 
This page intentionally left blank 


\section{INTRODUCTION}

Small specimens are playing the key role in evaluating properties of irradiated materials. The use of small specimens provides several advantages. Typically, only a small volume of material can be irradiated in a reactor at desirable conditions in terms of temperature, neutron flux, and neutron dose. A small volume of irradiated material may also allow for easier handling of specimens. Smaller specimens reduce the amount of radioactive material, minimizing personnel exposures and waste disposal. However, use of small specimens imposes a variety of challenges as well. These challenges are associated with proper accounting for size effects and transferability of small specimen data to the real structures of interest.

Any fracture toughness specimen that can be made out of the broken halves of standard Charpy specimens may have exceptional utility for evaluation of reactor pressure vessels (RPVs) since it would allow one to determine and monitor directly actual fracture toughness instead of requiring indirect predictions using correlations established with impact data. The Charpy V-notch specimen is the most commonly used specimen geometry in surveillance programs.

A few years ago, the Central Research Institute of Electric Power Industry (CRIEPI) had developed the test technique for the miniature compact tension $[\mathrm{C}(\mathrm{T})]$ specimens (Mini-CT), whose dimensions are approximately $4 \times 10 \times 10 \mathrm{~mm}$. A round robin program had been organized with the participation of Japanese and International academia, industries and government institutes, including Oak Ridge National Laboratory (ORNL). The round robin program aimed to verify the reliability and robustness of experimental data of the Mini-CT among different laboratories. The ORNL results for the Mini-CT round robin contribution are summarized in [1]. It was shown that the Mini-CT specimens were offering a very attractive opportunity to derive the same fracture toughness transition temperature values, $\mathrm{T}_{\mathrm{o}}$, as those derived by larger fracture toughness specimens. Yet, the advantage of this Mini-CT specimen technique is that multiple specimens can be machined from one half of a broken Charpy specimen, used in a standard surveillance capsule of a reactor pressure vessel.

Based on the outcome of the ORNL contribution to the international round robin program [1], it was decided to extend such research to provide further assessment and validation of the Mini-CT test specimen geometry using a typical US reactor pressure vessel steels. A three steps plan has been adopted to address these needs. The first phase was aimed at performing fracture toughness characterization of a typical US reactor pressure vessel steel for which a very well characterized database has been already established by using various types of fracture toughness specimens larger than Mini-CT. This step has been completed last year using A533B Plate 13B testing [2]. The second phase should address the applicability of Mini-CT specimens for a typical reactor pressure vessel weld material. The final step would be validation of the Mini-CT specimen for irradiated material.

This report summarizes the results of the second phase of assessment and validation of Mini-CT test specimen geometry. In this study, Mini-CT specimens were used to perform fracture toughness characterization of low upper-shelf Linde 80 weld, designated WF-70, in the unirradiated condition. This weld was utilized in the Midland Reactor Unit 1 beltline weld and has been previously well characterized at the ORNL with various fracture toughness specimens [3-7]. The report is prepared in satisfaction of Milestone M2LW-17OR0402015- "Complete report on the development of MiniCompact Tension test methods for determining fracture toughness Master Curves for reactor pressure vessel steels." 


\section{MATERIAL DESCRIPTION}

In the 1990's, the Heavy Section Steel Irradiation Program at ORNL performed a very wideranging characterization program of the beltline weld from Midland Nuclear Power Plant Unit 1 in the unirradiated and irradiated conditions. The Unit 1 had been canceled and large pieces of various parts of the beltline and nozzle course welds from the RPV were removed and used for that study. The current study deals with the unirradiated beltline weld of this reactor which was a double-V submerged-arc (WF70) weld made with Heat No. 72105 weld wire and lot 8669 Linde- 80 flux.

The goal of that original program was to perform a very comprehensive characterization of chemical composition, Charpy impact toughness, drop weight nil-ductility, tensile, and fracture toughness properties of the beltline and nozzle course welds before and after irradiation in test reactors. For example, a total of 230 Charpy specimens were tested for impact toughness characterization of the beltline weld in the unirradiated condition. Fourteen 0.5T, thirty-five 1T, fourteen 2T, and two 4T compact tension and 19 precracked Charpy specimens were used to perform transition region fracture toughness characterization of the beltline weld in the unirradiated condition, see Figure 1. Based on the results of such a large number of conventional fracture toughness specimens, the reference transition fracture toughness temperature, $\mathrm{T}_{\mathrm{o}}$, was determined to be $-54^{\circ} \mathrm{C}$ for the unirradiated beltline weld. The detailed results of this program can be found in these publications [3-7].

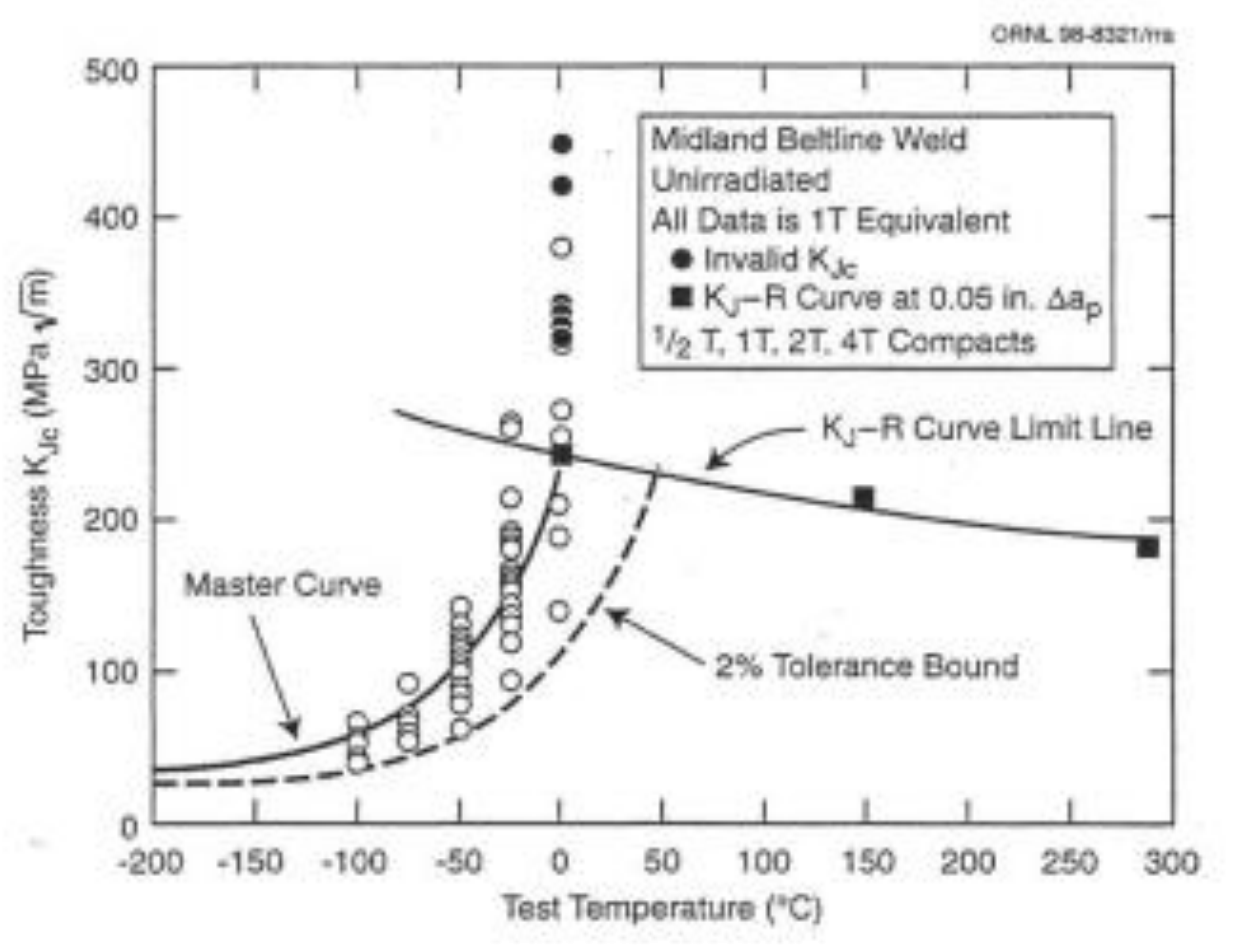

Figure 1. Unirradiated Midland beltline weld $K_{\mathrm{Jc}}$ data normalized to 1T equivalence; the master curve and $2 \%$ tolerance bound and $K_{J-R}$ curve limit curve [5].

The availability of such an ample data bank of the unirradiated properties by means of conventional fracture toughness specimens was one of the reasons for selecting this beltline material to perform validation of Mini-CT specimens for fracture toughness characterization of a lower upper-shelf weld material. Additionally, the irradiated Midland beltline weld was selected for a joint EPRI-CRIEPI- 
ORNL program for validation of Mini-CT specimens for irradiated weld material. Thus, this study would complement the future irradiated portion of the work on validation of Mini-CT specimens.

\section{TEST RESULTS AND ANALYSIS PROCEDURE}

Mini-CT specimens, see Figure 2, were machined from broken halves of Charpy impact specimens. While it is common to get four Mini-CT from one broken Charpy specimen of a base metal, only two specimens were possible to machine out of broken half of Charpy specimens containing the beltline weld. A slightly modified version of Mini-CT specimen is being used at ORNL. The main modification is related to use of grooves to allow an "outboard" clip gage with sharp razor blades to be placed such that load-line displacement can be directly measured for J-integral calculation rather than front face gage placement to avoid subsequent recalculation to load-line displacement. Moreover, from previous experience at the fracture mechanics laboratory at ORNL, it was determined that razor blades improved reliability and sensitivity as compared to integrated front-face cut-off notches like the one suggested in CRIEPI round robin specimen design [8-11]. Another advantage of this set-up is simplicity of handling such a small specimen and clip gage in the hot cell or other remote conditions. All specimens were fatigue precracked to the target a/W value of 0.5 , where $a$ is crack length and $W$ is a specimen width.

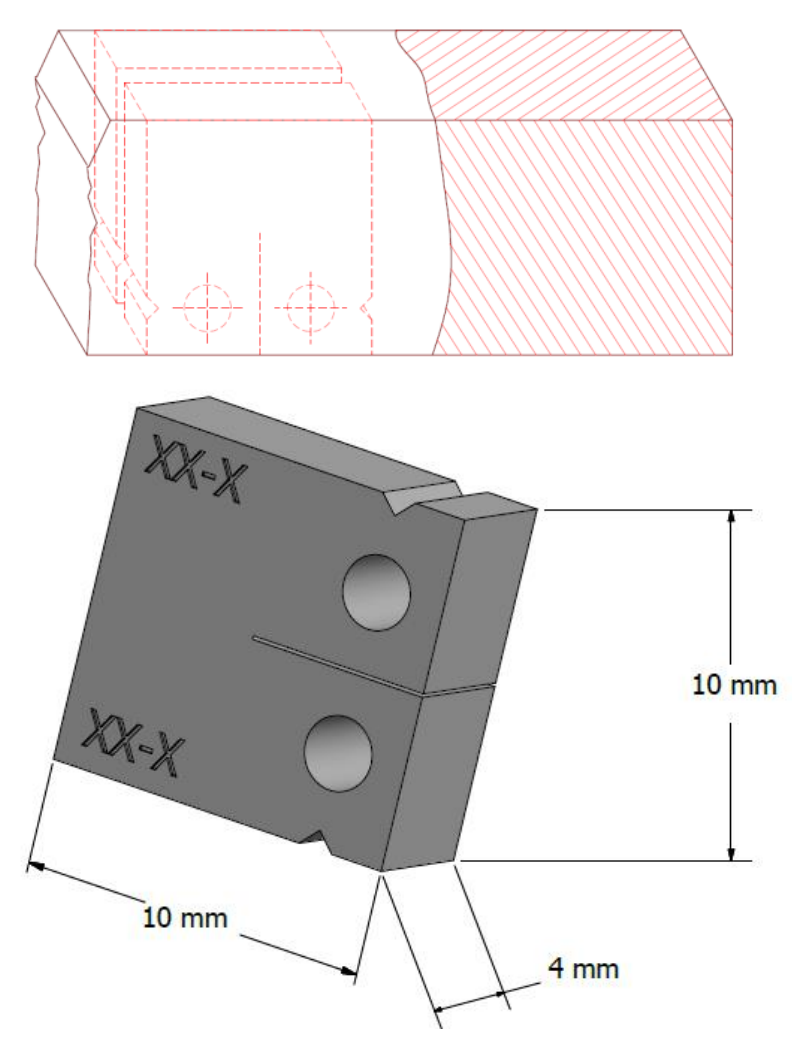

Figure 2. Layout of Mini-CT within broken Charpy half and overall dimensions of Mini-CT specimen. 
The testing was performed under carefully controlled conditions in accordance with ASTM E1921 such that the values can be compared to the fracture toughness performance of previously tested large specimens. The results are summarized in Table 1. A total of 11 specimens were tested in this study. Test temperature ranged from $-105^{\circ} \mathrm{C}$ to $-75^{\circ} \mathrm{C}$. The highest test temperature was selected to be $20^{\circ} \mathrm{C}$ lower than the $\mathrm{T}_{\mathrm{o}}=-54^{\circ} \mathrm{C}$, derived from substantial number of larger fracture toughness specimens as described above. This was based on the relatively small thickness of the Mini-CT specimen, 4-mm. One of the specimens, 9BK304, tested at $-75^{\circ} \mathrm{C}$ did not cleave. All other specimens cleaved and all measured $\mathrm{K}_{\mathrm{Jc}}$ values were within the validity limit of E1921 as per equation:

$$
K_{J c \text { (limit) }}=\sqrt{\frac{E\left(W-a_{o}\right) \sigma_{Y S}}{30\left(1-v^{2}\right)}}
$$

For specimen 9BK304, the stress-intensity factor that corresponds to the final $\mathrm{J}$-integral, $\mathrm{K}_{\mathrm{Jmax}}$, is reported in Table 1 instead of the stress-intensity factor at the cleavage instability, $\mathrm{K}_{\mathrm{Jc}}$.. as for the rest of the specimens. This result was censored and $\mathrm{T}_{\mathrm{o}}$ was analyzed according to the ASTM E1921 procedure for a dataset with censored values.

Table 1. Fracture toughness of Midland beltline weld as measured by Mini-CT specimens.

\begin{tabular}{|c|c|c|c|}
\hline Specimen ID & Test $\mathrm{T},{ }^{\circ} \mathrm{C}$ & $\mathrm{K}_{\mathrm{Jc}}, \mathrm{MPa} \sqrt{\mathrm{m}}$ & $\mathrm{T}_{\mathrm{o}},{ }^{\circ} \mathrm{C}$ \\
\hline 9B1102 & -75 & 77.4 & \multirow[t]{11}{*}{-53} \\
\hline 9B1103 & -75 & 122.9 & \\
\hline 9B1104 & -90 & 91.0 & \\
\hline 9BK303 & -90 & 59.7 & \\
\hline 9BK305 & -90 & 117.1 & \\
\hline 9BK306 & -90 & 79.1 & \\
\hline 9BK307 & -90 & 73.2 & \\
\hline 11B1101 & -90 & 102.8 & \\
\hline 11B1103 & -75 & 121.5 & \\
\hline 11B1104 & -105 & 67.0 & \\
\hline 9BK304 & -75 & 234.8 & \\
\hline
\end{tabular}

Note, that the first round of calculations yielded a $\mathrm{T}_{\mathrm{o}}$ value of $-52^{\circ} \mathrm{C}$. Since specimen $11 \mathrm{~B} 1104$ was tested outside the $T_{0}-50^{\circ} \mathrm{C}$ range, this specimen was excluded for final $T_{o}$ calculation. Figure 3 presents the fracture toughness data of the Mini-CT specimens tested in this study together with corresponding Master Curve, $2 \%$ and $98 \%$ tolerance bounds. 


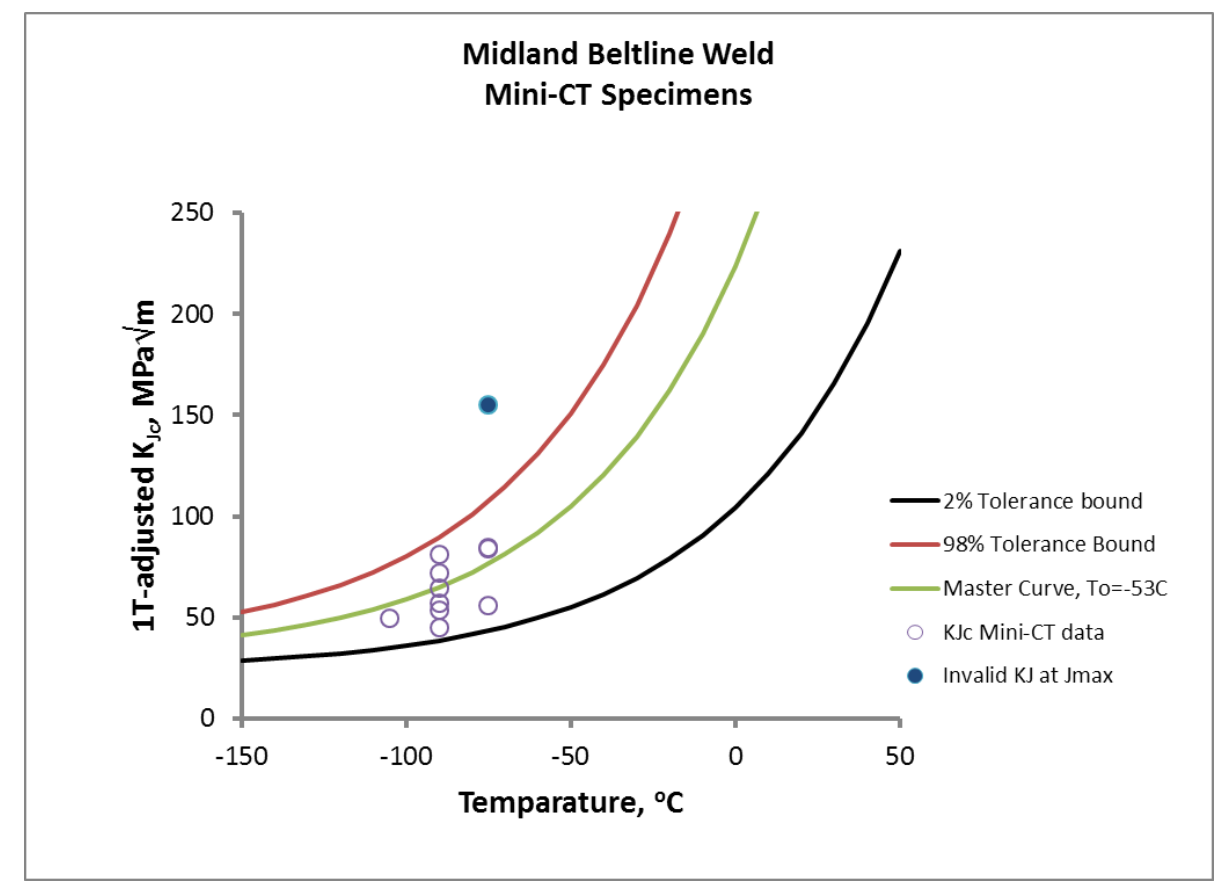

Figure 3. Fracture toughness of Midland beltline weld determined by Mini-CT specimens.

\section{DISCUSSION}

The $T_{0}$ value derived from a relatively small number of Mini-CT specimens in this study is in remarkable agreement with the $\mathrm{T}_{\mathrm{o}}$ value previously reported for a much larger number of conventional fracture toughness specimens. This again verifies the ability of such a small Mini-CT specimen to determine the reference fracture toughness temperature of a reactor pressure vessel material that is the same as that derived from tests of larger, more conventional type of fracture toughness specimens. These results also emphasize the need for testing an extra number of such small specimens. For example, in this study, a total of 11 Mini-CT specimens were used for fracture toughness characterization. However, this was not a "blind" test and selection of the test temperature was based on a large dataset of previously tested conventional specimens. The initial test temperature was selected to be around $20^{\circ} \mathrm{C}$ below $\mathrm{T}_{\mathrm{o}}$ and, yet, one specimen did not cleave. It forced performance of testing at even lower temperature. As a result, the specimen that was tested at the lowest temperature had to be excluded from $T_{\mathrm{o}}$ calculation because it was outside the applicability window. Thus, in cases when the expected $\mathrm{T}_{\mathrm{o}}$ value is less defined than here, even more specimens might be lost due to strict validity requirements of the ASTM E1921 standard before the final $\mathrm{T}_{\mathrm{o}}$ is determined.

\section{SUMMARY}

The ability of a small number of Mini-CT specimens to determine the fracture toughness reference temperature, $T_{0}$, of a low upper-shelf material has been examined on the unirradiated Linde 80 WF-70 weld. These Mini-CT specimens were machined from broken halves of previously tested Charpy specimens as part of the Midland beltline weld characterization. The $\mathrm{T}_{\mathrm{o}}$ value derived from a relatively small number of Mini-CT specimens in this study is in remarkable agreement with the $T_{o}$ value previously reported from a much larger number of conventional fracture toughness specimens. At the 
same time, this study indicates that in real practice it is highly advisable to use a much larger number of specimens than the minimum amount prescribed in ASTM E1921.

\section{REFERENCE}

1. "Results of Fracture Toughness Tests for the Round Robin Test Program Using Mini-Compact Specimens" by M.A. Sokolov, ORNL report, ORNL/LTR-2014/686, December 2014.

2. "The Assessment and Validation of Mini-Compact Tension Test Specimen Geometry and Progress in Establishing Technique for Fracture Toughness Master Curves for Reactor Pressure Vessel Steels" by M.a. Sokolov, ORNL report, ORNL/LTR-2016/602.

3. "Chemical Composition and RT $\mathrm{NDT}_{\mathrm{N}}$ Determinations for Midland Weld WF-70" by R. K. Nanstad, D. E. McCabe, R. L. Swain, M. K. Miller, NUREG/CR-5914 (ORNL-6740), 1992.

4. "Unirradiated Material Properties of Midland Weld WF-70" by D.E. McCabe, R.K. Nanstad, S.K. Iskander, and R.L. Swain. NUREG report NUREG/CR-6249, October 1994.

5. "Evaluation of WF-70 Weld Metal From the Midland Unit 1 Reactor Vessel” by D.E. McCabe, R.K. Nanstad, S.K. Iskander, D.W. Heatherly, and R.L. Swain. NUREG report NUREG/CR5736, November 2000.

6. "Evaluation of Variability in Material Properties and Chemical Composition for Midland Reactor Weld WF-70," by R. K. Nanstad, D. E. McCabe, and R. L. Swain, in 18th International Symposium on Effects of Radiation on Materials, ASTM STP 1325, 1996, pp 125-156.

7. "Effects of Irradiation and Thermal Annealing on Fracture Toughness of Midland Reactor Weld WF-70," by D. E. McCabe, R. K. Nanstad, and M. A. Sokolov, in 19th International Symposium on Effects of Radiation on Materials, ASTM STP 1366, 1998, pp 306-319.

8. "A Round Robin Program of Master Curve Evaluation Using Miniature C(T) Specimens -First Round Robin Test on Uniform Specimens of Reactor Pressure Vessel Material," by M. Yamamoto, A. Kimura, K. Onizawa, K. Yoshimoto, T. Ogawa, A. Chiba, T. Hirano, T. Sugihara, M. Sugiyama, N. Miura and N. Soneda, PVP2012-78661, In Proceedings of the ASME 2012 Pressure Vessels and Piping Conference, 2012.

9. "International Round Robin Program on Master Curve Reference Temperature Evaluation Utilizing Miniature C(T) Specimen" by M. Yamamoto, K. Onizawa, K. Yoshimoto, T. Ogawa, Y. Mabuchi, M. Valo, M. Lambrecht, H.W. Viehrig, N. Miura and N. Soneda, ASTM STP 1576, 2014.

10. "Round Robin Program of Master Curve Evaluation Using Miniature C(T) Specimens - 2nd Report: Fracture Toughness Comparison in Specified Loading Rate Condition,” by M. Yamamoto, K. Onizawa, K. Yoshimoto, T. Ogawa, Y. Mabuchi, and N. Miura, PVP201397936. In Proceedings of the ASME 2013 Pressure Vessels and Piping Conference, 2013.

11. "A Round Robin Program of Master Curve Evaluation Using Miniature C(T) Specimens -3rd Report: Comparison of To under Various Selections of Temperature Conditions," by M. Yamamoto, A. Kimura, K. Onizawa, K. Yoshimoto, T. Ogawa, Y. Mabuchi, H.W. Viehrig, N. Miura, and N. Soneda, PVP2014-28898, In Proceedings of the ASME 2014 Pressure Vessels and Piping Conference, 2014. 
This page intentionally left blank 
ORNL/TM- 2017/275

\section{INTERNAL DISTRIBUTION}

1. K. J. Leonard

3. T. M. Rosseel

5. D. Williams
2. R. K. Nanstad

4. M. A. Sokolov

6. X. Chen

\section{EXTERNAL DISTRIBUTION}

6. J. Wagner, Idaho National Laboratory, P.O. Box 1625, Idaho Falls, ID 83415-3860,

7. R. Reister, GTN Bldg., 1000 Independence Ave, S.W. Washington, DC 20585, 